Arzu Uyanık Parlak ๑ Hüseyin Güdücüoğlu $\odot$

Mehmet Parlak ๑

Yasemin Bayram ๑

Barış Otlu ๑

\title{
The Investigation of OXA-48 and Sub-Derivatives in Klebsiella pneumoniae Strains and Phenotypic Reflection
}

öz

Hastane enfeksiyonları içinde karbapenem dirençli Gram negatif bakterilerin etken olduğu enfeksiyonların sayısı giderek artmaktadır. Bu bakteriler genellikle diğer grup antibiyotiklere de dirençli olduklarından dolayı sağlık için ciddi bir tehdit oluşturmaktadırlar. Çalışmada çeşitli klinik örneklerden izole edilen Klebsiella pneumoniae izolatlarında OXA-48 ve alt türevlerinde karbapenemaz direncinin fenotipik ve genotipik yöntemlerle belirlenmesi ve direnç gözlenmeyen izolatlarda genotipik olarak OXA-48 gen bölgesinin var olup olmadığının araştırılması hedeflenmiştir.

Çalışmaya Mart 2015-Mart 2016 yılları arasında polikliniklere başvuran veya çeşitli servis ve yoğun bakım ünitelerinde tedavi gören hastalardan izole edilen $127 \mathrm{~K}$.pneumoniae izolatı dâhil edilmiștir. BD Phoenix otomatize sistemiyle identifikasyonu ve antibiyogramı yapılan izolatların antibiyotiklere duyarlılıları Kirby-Bauer disk difüzyon yöntemiyle de tespit edilmiştir. OXA-48 tipi enzimlerin varlığını gösterdiği kabul edilen temosilin diski ile fenotipik olarak direnç varlığına bakılmıstır. Tüm izolatlarda "in-house" polimeraz zincir reaksiyonu (PZR) ile OXA-48 tipi enzimin varlığı araştırılmış ve pozitif saptanan izolatlara DNA dizi analizi yapılarak OXA48 varyant varlığına bakılmıştır.

Karbapenem direnç oranı \% 35 ve GSBL pozitifliği ise \% 46 olarak tespit edilmiștir. Temosilin disk yönteminin K.pneumoniae suşlarında OXA-48 gen varlığını saptamadaki duyarlılığı \% 88; özgüllüğü \% 89 olarak bulunmuştur. OXA-48 varlığına bağlı gelişen karbapenem direncini saptamada duyarlıık ve özgüllük dengesi için en iyi karbapenemin ertapenem olduğu gözlenmiştir. Otomatize sistemle karbapenemlere dirençli olarak tespit edilen K.pneumoniae izolatlarında bla ${ }_{\text {oxa-48 }}$ gen bölgesi varlığı \% 80 bulunmuştur. OXA-48 pozitif olarak saptadığımız 42 izolatta yapılan DNA dizi analizi ile elde edilen tüm dizilerin OXA-48 olduğu ve diziler içinde varyant OXA-48 geni bulunmadığı tespit edilmiștir. Genotipik olarak OXA-48 gen bölgesine sahip üç izolatta direncin fenotipik olarak yansımasının doğrudan doğruya ortaya çıkmadığı gözlenmistir. Karbapenemlere dirençli K.pneumoniae izolatlarındaki bla ${ }_{\text {oxa-48 }}$ gen bölgesi varlığı yaygındır. Bunun yanında OXA-48 gen bölgesine sahip bazı izolatlarda direncin fenotipik olarak yansımasının hemen ortaya çıkmaması nedeniyle tedaviye rağmen iyileșmeyen hastalarda bu tip izolatların olabileceği akılda tutulmalıdır.

Anahtar kelimeler: fenotipik yansıma, karbapenem, K.pneumoniae, OXA-48

\section{ABSTRACT}

The number of infections caused by carbapenem-resistant Gram negative bacteria is increasing among nosocomial infections. These bacteria are a serious threat to health because they are usually resistant to other antibiotics. This study was aimed to determine the carbapenemase resistance of OXA-48 and its subderivatives in Klebsiella pneumoniae isolates isolated from various clinical samples by phenotypic and genotypic methods and to investigate the presence of OXA-48 gene region genotypically in isolates without resistance.

A total of 127 K.pneumoniae strains isolated from patients treated in various clinics and intensive care units were included in this study from March 2015 to March 2016. The isolates were identified and susceptibilities were tested using BD Phoenix automated system and also with Kirby-Bauer disk diffusion method. The presence of resistance was examined phenotypically with the disk of temosillin, which is considered to indicate the presence of OXA-48 type enzymes. The presence of OXA-48 type enzyme was investigated by "in-house" polymerase chain reaction (PCR) in all isolates and the presence of OXA-48 variant was investigated by DNA sequencing analysis on positive isolates.

Carbapenem resistance rate was $35 \%$ and ESBL positivity was determined as $46 \%$. The sensitivity of temocillin disk method in the identification of OXA-48 gene presence in K. pneumoniae strains was found to be $88 \%$, and specificity $89 \%$. Ertapenem was the best carbapenem with sensitivity and specificity balance to detect carbapenem resistance caused by OXA-48. The presence of bla gene region was $80 \%$ in $\mathrm{K}$. pneumoniae isolates detected as resistant to carbapenems by an automated system. All sequences obtained by DNA sequence analysis of 42 OXA-48 positive isolates were OXA-48 and there was no variant OXA-48 gene among the sequences. It was observed that the phenotypic reflection of resistance did not occur immediately in three isolates genotypically having OXA-48 gene region.

The presence of bla ${ }_{O X A-48}$ gene region in carbapenems-resistant K.pneumoniae isolates is common. In addition, in some isolates having OXA-48 gene region, should be kept in mind in patients who do not recover despite treatment, due to phenotypic reflection of resistance does not occur immediately.

Keywords: carbapenem, K.pneumoniae, OXA-48, phenotypic reflection

Received/Geliş: 07.10.2020
Accepted/Kabul: 22.02.2021
Published Online/Online Yayın: 29.04.2021

Atıf/Cite as: Uyanık Parlak A, Güdücüoğlu $\mathrm{H}$, Parlak M, Bayram Y, Otlu B. Klebsiella pneumoniae suşlarında OXA-48 ve alt türevlerinin araştırılması ve fenotipik yansıma. ANKEM Derg. 2021;35(1):1-8.

Mehmet Parlak

Van Yüzüncü Yıl Üniversitesi

Tıp Fakültesi,

Tıbbi Mikrobiyoloji Anabilim Dalı,

Van, Türkiye

- mehmetparlak65@hotmail.com ORCID: 0000-0001-6030-2244

A. Uyanık Parlak 0000-0003-1048-8268 Ankara Atatürk Gögüs Hastalıkları ve Göğüs Cerrahisi Eğitim ve Araştırma Hastanesi, Mikrobiyoloji Laboratuvarı,

Ankara, Türkiye

H. Güdücüoğlu 0000-0003-1048-8268 Y. Bayram 0000-0001-6083-5550 Van Yüzüncü Yıl Üniversitesi Tıp Fakültesi Tıbbi Mikrobiyoloji Anabilim Dalı, Van, Türkiye

B. Otlu 0000-0002-6220-0521 Inönü Üniversitesi Tıp Fakültesi, Tıbbi Mikrobiyoloji Anabilim Dalı, Malatya Türkiye 


\section{Giriş}

Klebsiella cinsi bakteriler, tedavi edilmediğinde yüksek ölüm oranlarına sahip toplum kaynaklı bakteriyel pnömoni etkeni olabilmektedir. Nozokomiyal enfeksiyonlardan sorumlu esas bakteri Klebsiella pneumoniae olup, bu cinsin medikal olarak en önemli türüdür. İnsanların nazofarinksinde ve intestinal sisteminde saprofit olarak bulunmaktadır. Dışkı örneklerinde tespit oranı \% 5 ile \% 38 arasında değişirken, nazofarenksteki oranlar \% 1 ile \% 6 arasında değişmektedir. Bu taşıyıcılık oranları, kolonizasyon oranlarının kalış süresiyle doğru orantılı olarak arttığı hastane ortamında büyük ölçüde değişir.

Hastanede yatan hastalarda bildirilen taşıyıcı oranları dışkıda $\% 77$, farinkste $\% 19$ ve hastaların ellerinde \% 42' dir $^{(19)}$.

Bu yüzyııın başlarından itibaren genişlemiş spektrumlu beta-laktamaz (GSBL), Enterobactericeae üyeleri arasında hızla yayılmıştır. Son yıllarda bu yayılım kontrolden çıkmıs ve toplum kaynaklı enfeksiyonlar olarak karşımıza çıkmaya başlamıştır. GSBL üreten K.pneumoniae enfeksiyonlarında kullanılabilecek az sayıdaki etkili ajanlar arasında en güvenilir olanı ise karbapenemlerdir. Karbapenem dirençli K.pneumoniae izolatlarının ortaya çıkışı hem tedavi seçeneklerini kısıtlamakta hem de morbidite ve mortaliteyi artırmaktadır. Ayrıca karbapenemaz üreten Enterobactericeae üyeleri, tigesiklin ve polimiksin dışındaki ajanlara karşı dirence sahip olduklarından ciddi bir tehdit oluşturmakta ve dikkatle takip edilmeleri gerekmektedir ${ }^{(2,16)}$.

Karbapenemazlar, fonksiyonel sınıflamada grup $2 d, 2 f$ ve 3 'te, Ambler moleküler sınıflamada ise A, B ve $D$ sınıfı içerisinde bulunmaktadır. Sınıf $D$ içerisinde OXA enzimleri bulunmaktadir ${ }^{(1)}$. Bu gruptan OXA-48 ilk olarak ülkemizde, İstanbul'da karbapenem dirençli bir K.pneumoniae izolàtında tanımlanmıştır. Bu izolat ayrıca sınıf A GSBL olan SHV-2a, dar spektrumlu beta-laktamaz TEM-1 ve OXA-47'yi bulundurmaktadır. OXA-48 beta-laktamazı penisilinleri ve penisilinlerden daha düşük düzeyde imipenemi hidrolize etmektedir fakat geniş spektrumlu sefalosporinlere karşı aktif değildir. Bu enzim, imipenem için bilinen en yüksek katalitik aktiviteye sahip sınıf $D$ $\beta$-laktamazdır. Diğer sınıf $D$ beta-laktamazları ile olan aminoasit benzerliği \% 46'dan daha azdır ve OXA-23 ve OXA-40 ile zayıf benzerliğe sahiptir (sırasiyla $\% 36$ ve $\% 32)^{(20)}$.
Çalışmamızda; çeşitli klinik örneklerden izole edilen K.pneumoniae izolatlarında OXA-48 tipi (OXA48 ve varyantların) karbapenemaz direncinin fenotipik ve genotipik yöntemlerle belirlenmesi fenotipik olarak karbapenem direnci göstermeyen izolatların direnç genlerine sahip olup olmadığının tespit edilmesi ve ülkemize ait epidemiyolojik verilere katkı sağlamak amaçlanmıştır.

\section{GEREÇ VE YÖNTEM}

\section{Örneklerin Toplanması:}

Çalışma, Mart 2015-Haziran 2016 tarihleri arasında Tıbbi Mikrobiyoloji Laboratuvarı́nda yapılmıştır. Çalışmaya çeşitli klinik örneklerden enfeksiyon etkeni olarak izole edilmiş ve Phoenix100 (Becton Dickinson, $A B D$ ) otomatize sistemi ile karbapenemlere duyarlı, orta dirençli veya dirençli olarak belirlenen 127 K.pneumoniae izolatı dahil edilmiştir. Bir hastadan birden fazla izolat çalışmaya dahil edilmemiştir.

Mikrobiyoloji laboratuvarına gönderilen klinik örnekler \% 5 koyun kanlı agar (RTA, Türkiye) ve Eozin Metilen Mavisi agar (Oxoid, İngiltere) besiyerlerine ekimler yapılmıştır. Gram boyama ile Gram negatif basil morfolojisinde olan tüm izolatların tür tanımlanması otomatize Phoenix 100 bakteri tanımlama sistemi ile yapılmıştır. K.pneumoniae olarak tanımlanan izolatlar $-80^{\circ} \mathrm{C}^{\prime}$ de derin dondurucuda (Sanyo, Japonya) saklanmıştır.

Tüm izolatlar için antibiyotik duyarlılık testleri ve GSBL tespiti Kirby-Bauer disk difüzyon yöntemi ve Phoenix100 (Becton Dickinson, ABD) otomatize sistemi panelleri kullanılarak yapılmıştır. Sonuçlar 2015 yılında Clinical and Laboratory Standards Institute (CLSI) ve 2016 yllında ise European Committee on Antimicrobial Susceptibility Testing (EUCAST) kriterlerine göre değerlendirilmiştir ${ }^{(8,24)}$.

Temosilin disk difüzyon testi için plaklara $30 \mu \mathrm{g}$ temosilin (Mast Diagnostics, Merseyside, Birleşik Krallık) içeren antibiyotik diski yerleştirilip $35-37^{\circ} \mathrm{C}^{\prime} \mathrm{de}$ 18-24 saatlik inkübasyona bırakılmıştır. İnhibisyon zon çapı $\leq 10 \mathrm{~mm}$ ise yüksek temosilin direnci olarak değerlendirilmiştir.

Polimeraz Zincir Reaksiyonu (PZR):

Bu yöntemle K.pneumoniae izolatlarında OXA-48 ve varyantı olan (OXA-162, OXA-163, OXA-181, OXA204, OXA-232) karbapenemaz direnç geni varlığı araştırılmıştır. DNA izolasyonunda Exgene ${ }^{\mathrm{TM}}$ Clinic SV Mini kit (GeneAll, Güney Kore) kullanılmıştır. Kullanılan primerler Monteiro ve ark.'nın ${ }^{(15)}$ çalışmasından alınmıştır (Tablo 1). 
Tablo 1. Karbapenemaz genlerinin saptanması amacıyla kullanılan primer dizileri.

\begin{tabular}{cccc}
\hline Gen & Primer & Sekans(5'-3') & Kaynak \\
& & & \\
\hline bla $_{\text {OXA-48 }}$ & OXA-48-F & TGTTTTTGGTGGCATCGAT & 10 \\
\hline OXA-48A & OXA-48-R & GTAAMRATGCTTGGTTCGC & \\
OXA-48B & & TTGGTGGCATCGATTATCGG & 13 \\
\hline
\end{tabular}

Amplifikasyon için SensoQuest Labcycler (SensoQuest Biomedizinische, Almanya) cihazı kullanılmıştır. İzole edilen DNA ile Taq DNA polimeraz (Geneall, Güney Kore) kitinin önerisi doğrultusunda reaksiyon karışımı hazırlanmıştır.

\section{OXA-48 ve Diğer Varyantların Tespiti:}

Bakteriyel DNA izolasyonu, QIAamp DNA Mini Kit (Qiagen-Hilden, Almanya) ile yapılmıştır. PCR ile OXA48-like gen bölgesinin çoğaltılması aşamasında bilinen tüm bla OXA-48-like genlerinin amplifikasyonu için kullanılan primerler Tablo 1 'de verilmiştir. PCR sonrasında ürünlerin \% 1,5'luk agaroz jelde, $1 \mathrm{X}$ TBE tamponunda 1 saat elektroforez yapılmıştır. Elektroforez işlemi sonrası oluşan bantlar jel görüntüleme sisteminde (Gel logic 2200 imaging system, Kodak Company, NY, $A B D$ ) görüntülenmiştir. 743bp büyüklüğündeki bantlar OXA-48-like geni pozitif olarak değerlendirilmiştir.

\section{PCR ürünlerinin dizileme için saflaştırılması:}

PCR sonucunda elde edilen amplifikasyon ürünleri, DNA saflaştırma işlemine alınmıştır. Bu amaçla ticari bir saflaştırma kiti (Qiaquick PCR purification Kit, Qiagen, Almanya) kullanılmıştır. Üretici firmanın önerileri doğrultusunda uygulanan protokol uygulanmıştır. İşlem sonunda elde edilen ürünlerin saflığı \% $1,5^{\prime}$ luk agaroz jelde yürütülerek kontrol edilmiş ve yeterli miktarda DNA içeren saflaştırılma ürünleri sekans reaksiyonunda kullanılmak üzere $-20^{\circ} \mathrm{C}^{\prime} \mathrm{de}$ saklanmıştır.

DNA dizi analizi için sekans reaksiyonu; çift yönlü olarak her iki primerle yapılmıştır. Döngüsel dizileme için amplifikasyon koşulları 45 döngü boyunca $96^{\circ} \mathrm{C}^{\prime}$ de 10 saniye, $50^{\circ} \mathrm{C}^{\prime}$ de 5 saniye ve $60^{\circ} \mathrm{C}^{\prime}$ de 4 dakika olarak uygulanmıştır (Gene Amp PCR System 9700, Applied Biosystems, ABD).

\section{Sonuçların Analizi:}

Dizileme sonuçlarını içeren kromatogram dosyaları FinchTV v1.3.1 yazılımına (GeoSpiza Inc., ABD) aktarılarak, diziler görsel olarak incelenmiş ve gerekli görülen düzeltmeler yapılmıştır. Suşların elde edilen OXA-48-like gen dizileri Ugene yazılım kullanılarak (hhtp://ugene.unipro.ru), tüm diziler hizalanmıştır. Bunun yanında OXA-48 tipini (varyantını) belirlemek için National Centre for Biotechnology Information (NCBI) içinde yer alan GenBank ve Nucleotide ve Protein BLAST (Basic Local Alignment Tool) sunucuları kullanılmıştır.

\section{BULGULAR}

Çalışmaya, her biri ayrı hastalardan izole edilen 47 adet karbapenem dirençli ve 80 adet karbapeneme duyarlı olmak üzere 127 K.pneumoniae izolatı dahil edilmiştir. Çalışmaya alınan izolatların 77'si (\% $60,6)$ erkek, 50'si $(\%$ 39,4) kadın hastalardan izole edilmiştir. Hastaların 58'i polikliniklere başvuru yapan hastalardan, 69'u ise farklı servis ve yoğun bakım ünitelerinde takip edilen hastalardan oluşmaktadır. İzolatlar en fazla sırasıyla pediatri (\% 47), anestezi (\% 16), üroloji (\% 10) ve dahiliyeden (\% 9) elde edilmiştir. Örneklerin çoğunluğunu idrar örnekleri oluştururken (\% 66), bunu sırasıyla kan (\% 17), yara (\% 5) ve solunum yolu örnekleri (\% 3) takip etmiştir. İzolatların antibiyotiklere duyarlılık sonuçları Tablo 2'de verilmiştir.

Tablo 2. Klebsiella pneumoniae izolatlarının karbapenemlere duyarlılık test sonuçları.

\begin{tabular}{lccccccccc} 
& \multicolumn{3}{c}{ Phoenix (Mik) } & \multicolumn{3}{c}{ Disk Difüzyon } \\
\cline { 2 - 8 } Antibiyotik & $\mathbf{n}$ & $\mathbf{S}$ & $\mathbf{I}$ & $\mathbf{R}(\%)$ & $\mathbf{n}$ & $\mathbf{S}$ & $\mathbf{I}$ & $\mathbf{R}(\%)$ \\
\hline Ertapenem & 122 & 76 & & $\begin{array}{c}44 \\
(36,1)\end{array}$ & 127 & 86 & 6 & $\begin{array}{c}35 \\
(27,6)\end{array}$ \\
\hline Imipenem & 121 & 90 & 12 & $\begin{array}{c}19 \\
(15,7)\end{array}$ & 127 & 87 & 7 & $\begin{array}{c}33 \\
(26,0)\end{array}$ \\
\hline & 122 & 97 & 5 & $\begin{array}{c}20 \\
(16,4)\end{array}$ & 127 & 90 & 6 & $\begin{array}{c}31 \\
(24,4)\end{array}$ \\
Meropenem & 122 & & & & & & & \\
S: Duyarlı & & & & & & & & \\
I: Duyarl, yüksek doz & & & & & & & \\
R: Dirençli & & & & & & & &
\end{tabular}

K.pneumoniae izolatlarının \% 35'inde karbapenemlerden en az birine karşı direnç olduğu tespit edilmiştir. Ayrıca 127 K.pneumoniae izolatının 58'i (\% 46) GSBL pozitif olarak saptanmıştır. Fenotipik olarak temosilin disk difüzyon testi sonucuna göre 46 (\% 36) izolatta temosilin direnci saptanmıştır. İzolatların 42'sinde (\% 33) bla ${ }_{\text {OXA-48 }}$ gen bölgesi varlığı tespit edilmiş (Şekil 1), bunların 38'inde otomatize sistemle yapılan Mik sonuçlarına göre ertapenem, 
imipenem veya meropenemden birine direnç saptanmıştır. Diğer üç izolatta ise herhangi bir karbapeneme direnç belirlenmemiş̧ir (Tablo 3). bla ${ }_{\text {OXA-48 }}$ gen bölgesi varlığı tespit edilen 38 izolatın $35^{\prime}$ inde (\% 92) sefalosporin direnci (sefotaksim, seftazidim, sefepim) tespit edilmiştir.

Tablo 3. Çalışmaya alınan izolatlarda OXA-48 geni varlığı ile izolatların; ertapenem, imipenem, meropenem ve temosilin duyarlıık sonuçlarının karşılaştırılması.

\begin{tabular}{|c|c|c|c|c|}
\hline \multirow[t]{2}{*}{ Değer } & & \multicolumn{2}{|c|}{ OXA-48 } & \multirow{2}{*}{ Toplam } \\
\hline & & Pozitif & Negatif & \\
\hline \multirow{3}{*}{$\begin{array}{l}\text { Karbapenemlerden } \\
\text { herhangi birine } \\
\text { (Ertapenem } \\
\text { Imipenem } \\
\text { Meropenem) }\end{array}$} & $R$ & 38 & 10 & 48 \\
\hline & $s / 1$ & 4 & 75 & 79 \\
\hline & Toplam & 42 & 85 & 127 \\
\hline \multirow{3}{*}{ Ertapenem } & $\mathrm{R}$ & 34 & 10 & 44 \\
\hline & $S / I$ & 4 & 74 & 78 \\
\hline & Toplam & 38 & 84 & 122 \\
\hline \multirow{3}{*}{ İmipenem } & $\mathrm{R}$ & 15 & 3 & 18 \\
\hline & $s / l$ & 23 & 80 & 103 \\
\hline & Toplam & 38 & 83 & 121 \\
\hline \multirow{3}{*}{ Meropenem } & $\mathrm{R}$ & 16 & 4 & 20 \\
\hline & $s / 1$ & 22 & 80 & 102 \\
\hline & Toplam & 38 & 84 & 122 \\
\hline \multirow{3}{*}{ Temosilin } & $R$ & 37 & 9 & 46 \\
\hline & $s / 1$ & 5 & 76 & 81 \\
\hline & Toplam & 42 & 85 & 127 \\
\hline
\end{tabular}

S: Duyarlı

I: Duyarlı, yüksek doz

R: Dirençli
Karbapenemler ve temosilin diski sonuçlarına göre OXA-48 saptanması için duyarlılık ve özgüllük Tablo 4'te özetlenmiştir.

Tablo 4. Ertapenem, imipenem, meropenem ve temosilin için duyarlıık ve özgüllük sonuçları.

\begin{tabular}{lccccc} 
Antibiyotik & Duyarlılık & Özgüllük & PPD & NPD & Doğruluk \\
\hline Ertapenem & 89 & 88 & 77 & 95 & 89 \\
\hline Imipenem & 39 & 96 & 83 & 78 & 79 \\
\hline Meropenem & 42 & 95 & 80 & 78 & 78 \\
\hline Temosilin & 88 & 89 & 80 & 94 & 89
\end{tabular}

Çalışılan 127 örnekten 42'sinde OXA-48-like geni pozitif bulunmuştur. PZR ürünlerinin dizi analizi, yüksek oranda benzerlik olduğunu ortaya çıkarmıştır. Farklılıklar dizilemenin stabil olmadığı ilk ve son okumalarda gözlenmiştir. Dizilerin global hizalamaları değerlendirildiğinde tümünün OXA-48 olduğu (E value: 0.0 , Ident. $\geq \% 99$ ) ve diziler içinde varyant OXA-48 geni bulunmadığı tespit edilmiştir.

\section{TARTIŞMA}

Klebsiella izolatlarının izole edildiği klinik örneklerin dağılımı çeşitli çalışmalarda değişiklik göstermektedir. Temiz ve ark.'nın ${ }^{(23)}$ yaptıkları çalışmada Klebsiella spp. izolatlarını sıklık sırasıyla \% 41 idrar, \% 24 kan, \% 16 trakeal aspirat, \% 15 yara ve \% 4 diğer klinik örneklerinden izole etmişlerdir. Çalışmamızda da izolatların literatürle benzer klinik örneklerden

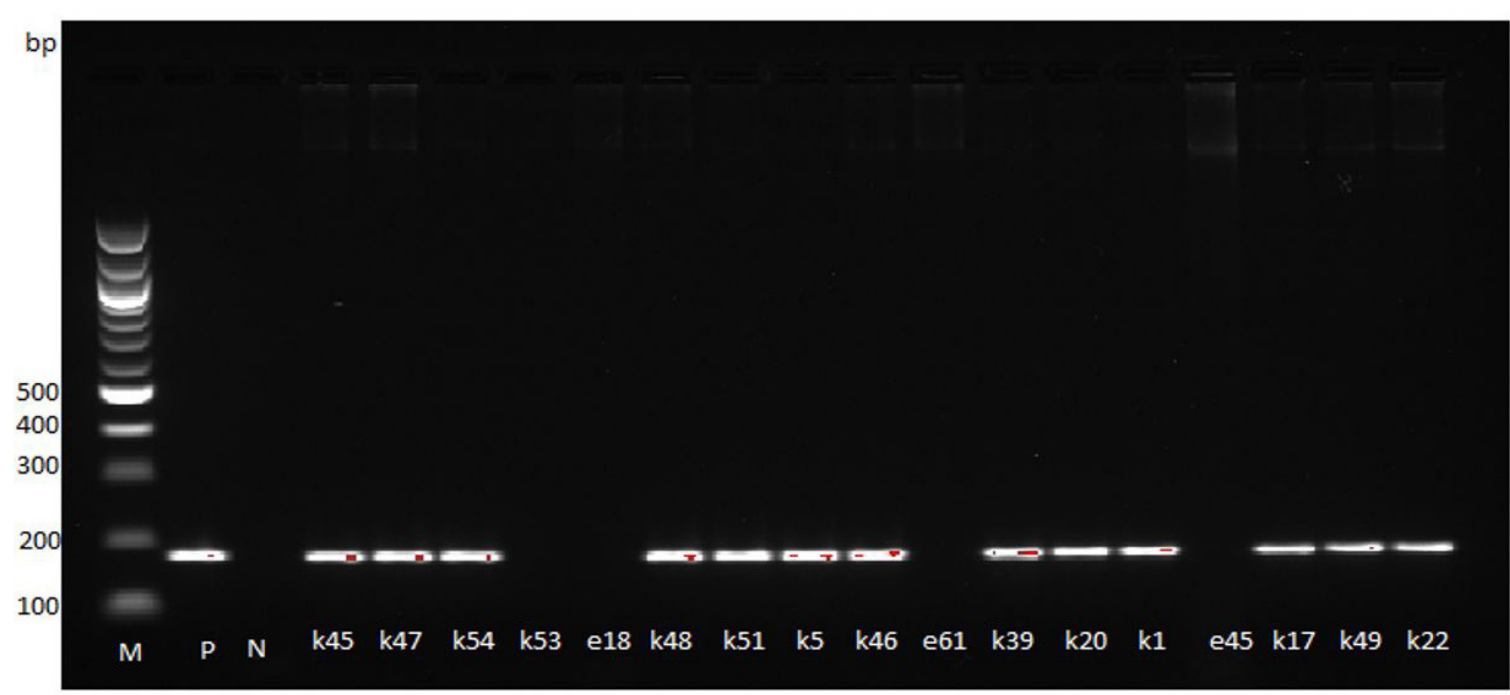

M, marker; P, pozitif kontrol; N, negatif kontrol; bp, base pair; k52, k42...., suş kodları

Şekil 1. K.pneumoniae izolatlarında OXA-48 pozitif gen bölgeleri. 
izole edildiği belirlenmiştir.

Enterobacteriaceae ailesinde karbapenem direnci 2000 yılından önce ihmal edilebilir bir olgu olarak görülmekteydi. Bu durum 1990'ların sonlarında K.pneumoniae'nin KPC-tipi karbapenemaz üretmesinin görülmesi ile değişmiştir ve 2000 'li yıllarda tüm dünyaya yayılmıştır. Bunu NDM-tipi karbapenemaz üreten Enterobactericeae ve OXA-48-tipi karbapenemaz üreten K.pneumoniae'lerin ortaya çıkması izlemiştir ${ }^{(5)}$.

CLSI ve EUCAST karbapenemaz üretiminin saptanması için farklı tarama önerileri sunmaktadır. CLSI tarama için ertapenemi önermektedir. Ancak, EUCAST ertapenemi duyarlılığının yüksek olmasına karşın özgüllüğünün düşük olmasından dolayı tercih etmemektedir. Bunun yerine, karbapenemaz taramasında duyarlılık ve özgüllük dengesinin uyumlu olması nedeniyle meropenemi önermektedir ${ }^{(8,24)}$. Ortega ve ark. ${ }^{(18)}$ çalışmalarında ertapenemin, OXA48 üreten E.coli taraması için imipenem veya meropenemden daha duyarlı olduğunu bulmuşlardır. Çakar ve ark. ${ }^{(4)}$ 'nın yaptıkları çalışmada OXA-48 enzimi içeren izolatların birçoğunu meropeneme duyarlı, ancak tamamı ertapeneme dirençli bulunmuş ve karbapenemaz taramasında ertapenemin en uygun antibiyotik olduğu saptanmıştır. Çalışmamızda imipenem ve meropenemin özgüllüklerinin birbirine yakın olduğu (sırasıyla \% 96 ve \% 95) saptanmıştır. Ancak, her iki karbapenemin de duyarlılıkları düşük (sırasıyla $\% 39$ ve \% 42) bulunmuştur. Çalışmamızda OXA-48 varlığına bağlı gelişen karbapenem direncini saptamada duyarlılık ve özgüllük dengesi en iyi karbapenemin ertapenem olduğu gözlenmiştir.

Zarakolu ve ark. ${ }^{(25)} 2016$ 'da yayınlanan çalışmalarında 279 karbapenem dirençli K.pneumoniae izolatının 270'inde OXA-48 benzeri karbapenemaz tespit etmiş olup tüm izolatlarda temosiline direnç tespit etmişlerdir. Teethaisong ve ark. ${ }^{(22) ' n ı n ~ t e m o s i l i n ~ d i s k ~}$ difüzyon yöntemi kullanarak yaptıkları çalışmada; temosilin diskinin meropenemin PBA veya EDTA ile yapılan sinerji testleri de negatif olduğu durumlarda OXA-48 varlığını saptamadaki duyarlılık ve özgüllüğünü \% 100 olarak bulmuşlardır. Florian ve ark. ${ }^{(9)}$ çalışmalarında OXA-48 benzeri karbapenemaz üreten tüm izolatlarında temosilinin duyarlıı̆ı̆ını \% 100 özgüllüğünü ise \% 43,9 olarak bulmuşlardır. Omnia ve ark. ${ }^{(17)} 2017$ 'de yaptıkları çalışmalarında temosilin diskinin OXA-48 varlığını saptamada duyarlılı̆ını \% 97,9 özgüllüğünü $\% 50$ olarak saptamışlardır.
Çalışmamızda temosilin diskinin duyarlıı̆̆ı \% 88 özgüllüğü ise \% 89 olarak bulunmuş olup OXA-48'in varlığını tespit etmek ve dışlamak için tek başına yeterli olmayacağı düşünülmektedir. (Tablo 4).

Haciseyitoglu ve ark. ${ }^{(11)}$ çalışmalarında karbepenem dirençli 44 K.pneumoniae izolatın 33'ünde OXA48 pozitifliği saptamışlardır. Ece ve ark. ${ }^{(6)}$ karbapenem dirençli 14 K.pneumoniae izolatı ile yaptıkları çalışmalarında tüm izolatlarda OXA-48 pozitifliği saptamışlardır. Yapılan çalışmalar ülkemizde OXA-48 üreticilerinin yaygın olduğunu göstermektedir ${ }^{(12,13)}$. Çalışmamızda otomatize sistemle karbapenemlerden en az birine dirençli olan 47 K.pneumoniae izolatının $38^{\prime}$ inde (\% 80) in-house PCR ile bla ${ }_{\text {oxA-48 }}$ gen bölgesi tespit edilmiştir ve çalışmamı sonucunda bulduğumuz sonuç literatürle uyum göstermektedir. Karbapenemlere dirençli olan bu 38 izolatın genişlemiş spektrumlu sefalosporinlere karşı direnç olması bu izolatlarda OXA-48 tipi enzimlerin yanısıra bir GSBL enziminin de olabileceğini düşündürmektedir. Karbapenem dirençli 38 izolatın 14'ünün tüm karbapenemlere (ertapenem, imipenem ve meropenem) dirençli olması bu izolatların ek olarak başka bir karbapenemaz geni taşıması veya dış membran porin defekti durumunu akla getirmektedir. ${ }^{(10)}$

Messaoudi ve ark. ${ }^{(14)} 2020$ 'de yayınlanan çalışmalarında 240 karbapenem dirençli K.pneumoniae izolatının 196'ında OXA-48 benzeri gen bulunmuştur ve içlerinden seçilen alt gruba ileri analiz yapılmış olup 27 K.pneumoniae izolatı arasında 10 ve 17 izolat, sırasıyla bla ${ }_{\mathrm{OXA}-48}$ ve bla ${ }_{\mathrm{OXA}-204}$ genlerini barındırmıştır. Erdem ve ark. (7) 2020'de yayınlanan 10 MDR K.pneumoniae izolatı ile yaptıkları çalışmalarında bir izolatlarında bla OXA-181 $_{1}$ geni tespit etmişlerdir. Çalışmamızda OXA-48 pozitif olarak saptadığımız 42 izolatta yapılan DNA dizi analizi ile elde edilen tüm dizilerin OXA-48 olduğu ve diziler içinde varyant OXA-48 geni bulunmadığı tespit edilmiş̧ir.

Carrer ve ark. ${ }^{(2)}$ çeşitli ülkelerden 18 OXA-48 pozitif klinik izolat (13 K.pneumoniae, 2 Enterobecter cloacaea, 1 Providencia rettgeri ve 1 Citrobacter freundii) toplayarak yaptıkları çalışmada izolatların disk difüzyon ve gradient testi ile antibiyotiklere duyarlılıklarını incelemişlerdir. OXA-48 pozitif olan 18 izolattan 14'ü karbapenemlere dirençli iken dört tanesi orta duyarlı veya duyarlı olarak saptanmıştır. Cuzon ve ark. ${ }^{(3)} 2008$ 'de Türkiye dışındaki ilk OXA-48 vakasını yayınlamışlardır. Phoenix (Becton-Dickinson, Erembodegem,Belçika) ve VITEK (bioMérieux, 
Fransa) ile izolat amoksisilin ve $A M C^{\prime} y e$ dirençli, geniş spektrumlu sefalosporinlere ve meropeneme duyarlı olarak bulunmuştur. Disk difüzyon ile imipenem ve meropenemin zon çaplarında azalma bulunurken ertapenem ise orta duyarlı olarak saptanmıştır. Gradient testi ile CLSI kriterlerine göre imipenem ve meropeneme duyarlı; aralı̆̆ında ertapeneme ise orta duyarlı bulunmuştur. PCR ve sekans analizi ile bla $_{\text {OXA-48 }}$ geni gösterilmiştir. Otomatize sistemlerin (Phoenix ve VITEK) karbapenem duyarlılığındaki azalmayı saptayamadığı ve bu yeni direnç mekanizmasının görüldüğünden daha yaygın olabileceği belirtilmiştir.

Çalışmamızda bla ${ }_{\text {OXA-48 }}$ gen bölgesini pozitif olarak saptadığımız üç izolatın otomatize sistemle belirlenen karbapenem MiK değerleri duyarlı sınırda bulunmuştur. Bu üç izolatın gradient test yöntemiyle de konfirmasyonu yapılmış ve yine duyarlı aralıkta olduğu tespit edilmiştir. İzolatların elde edildiği üç hastanın da geçmişinde hastanede yatış öyküsü bulunmaktadır. İki hastanın bakteriler izole edilmeden öncesinde ve sonrasında karbapenem tedavisi alıp almadıkları tespit edilememiştir. Son hasta ise izolat tespit edildikten sonra imipenem tedavisi almıştır ve tedaviye cevap vermiştir. OXA-48 pozitif olarak saptadığımız bir izolat ise otomatize sistemle ertapeneme dirençli tespit edilmiştir ancak gradient test yöntemiyle duyarlı olarak saptanmıştır. Çalışmamızda elde ettiğimiz veriler ve literatürdeki bilgiler ışı̆̆ında OXA-48 tipi direncin genotipik olarak varlığının fenotipik yansımasının doğrudan doğruya ortaya çıkmadığıdır ve böyle bir izolatla enfekte hastaların karbapenem tedavisine verdikleri cevap hakkındaki bilgilerimiz yetersiz kalmaktadır. OXA-48 tipi enzim üretiminin yaygın olduğu ülkemizde tedaviye rağmen iyileşmeyen hastalarda bu tip izolatların olabileceği akılda tutulmalıdır.

Sonuç olarak; hastanemizde izole edilen K.pneumoniae izolatları arasında karbapenem direnç oranı \% 35 ve GSBL pozitifliği ise \% 46 olarak tespit edilmiştir. Temosilin disk yönteminin K.pneumoniae suşlarında OXA-48 gen varlığını saptamadaki duyarlılığı \% 88, özgüllüğü \% 89 bulunmuştur ve literatürde bazı yayınlarda bahsedildiği kadar (\% 100) yüksek olmadığı görülmüştür. OXA-48 varlığına bağlı gelişen karbapenem direncini saptamada duyarlılık ve özgüllük dengesi en iyi karbapenemin ertapenem olduğu gözlenmiştir. Otomatize sistemle karbapenemlere dirençli olarak tespit edilen K.pneumoniae izolatla- rındaki bla $a_{\text {OXA-48 }}$ gen bölgesi varlığı \% 80 olarak bulunmuştur ve bu durum ülkemizde OXA-48 üreticilerinin yaygın olduğunu göstermektedir. Fenotipik testlerle sınıf D $\beta$-laktamazların fenotipik testlerle kolayca belirlenememesi ${ }^{(20)}$ genotipik olarak OXA-48 gen bölgesine sahip bazı izolatlarda direncin fenotipik olarak yansımasının doğrudan doğruya ortaya çıkmamasına neden olup tedaviye rağmen iyileşmeyen hastalarda bu tip izolatların olabileceği akılda tutulması gerekmektedir.

\section{Teşekkür}

Bu çalışma Van Yüzüncü Yıl Üniversitesi Bilimsel Araştırma Proje Başkanlığı Araştırma Fonu tarafından 2015-TF-B295 proje olarak desteklenmiştir. Van Yüzüncü Yıl Üniversitesi Bilimsel Araştırma Proje Başkanlığı'na teşekkür ederiz.

Moleküler testler, İnönü Üniversitesi Tıp Fakültesi Tıbbi Mikrobiyoloji Anabilim Dalı Moleküler laboratuvarında yürütülmüş olup yakın zamanda aramızdan ayrılan Dr. Öğr. Üy. Nafia Canan GÜRSOY'u rahmetle anıyoruz.

Etik Kurul Onayı: Van Yüzüncü Yıl Üniversitesi Tıp Klinik Araştırma Etik Kurulu'nun 26.02.2015 tarih 06 no.lu etik kurul onayı alınmıştır.

Çıkar Çatışması: Yazarlar tarafından herhangi bir çıkar çatışması bildirilmemiştir.

Ethics Committee Approval: The approval of the Medicine Clinical Research Ethics Committee of Van Yüzüncü Yıl University dated 26.02.2015 and numbered 06 was obtained

Conflict of Interest: No conflict of interest was declared by the authors.

\section{KAYNAKLAR}

1. Bush K and Jacoby GA. Updated functional classification of $\beta$-lactamases. Antimicrob Agents Chemother. 2010;54(3):969-76. https://doi.org/10.1128/AAC.01009-09

2. Carrër A, Poirel L, Yilmaz M, et al. Spread of OXA-48encoding plasmid in Turkey and beyond. Antimicrob Agents Chemother. 2010;54(3):1369-73. https://doi.org/10.1128/AAC.01312-09

3. Cuzon G, Naas T, Bogaerts P, Glupczynski Y, Huang TD, Nordmann P. Plasmid-encoded carbapenemhydrolyzing $\beta$-lactamase OXA-48 in an imipenemsusceptible Klebsiella pneumoniae strain from 
Belgium. Antimicrob Agents Chemother 2008;52(9):3463-4.

https://doi.org/10.1128/AAC.00543-08

4. Çakar A, Akyön Y, Gür D ve ark. Türkiye'de 2014 yılı içinde izole edilen karbapeneme dirençli Escherichia coli ve Klebsiella pneumoniae izolatlarında karbapenemaz varlığının araştırılması. Mikrobiyol Bul. 2016;50(1):21-33.

https://doi.org/10.5578/mb.10695

5. Doi Y, Paterson DL. Carbapenemase-producing Enterobacteriaceae. Semin Respir Crit Care Med. 2015;36(01):74-84.

https://doi.org/10.1055/s-0035-1544208

6. Ece $G$, Tunc E, Otlu B, et al. Detection of bla OXA-48 and clonal relationship in carbapenem resistant $\mathrm{K}$. pneumoniae isolates at a tertiary care center in Western Turkey. J Infect Public Health. 2018;11(5):6402.

https://doi.org/10.1016/j.jiph.2018.04.003

7. Erdem F, Abulaila A, Aktas Z, et al. In vitro evaluation of double carbapenem and colistin combinations against OXA-48, NDM carbapenemase-producing colistin resistant Klebsiella pneumoniae strains. Antimicrob Resist Infect Control. 2020;9:70.

https://doi.org/10.1186/s13756-020-00727-4

8. European Committee on Antimicrobial Susceptibility Testing. Breakpoint tables for interpretation of MICs and zone diameters. Version 5.0. 2015. Erişim adresi:[http://www.eucast.org] Erişim tarihi:01/06/2016.

9. Florian K, Stephan G, Martin K, et al. Comparison of Phenotypic Tests and an Immunochromatographic Assay and Development of a New Algorithm for Detection of OXA-48-like Carbapenemases. J Clin Microbiol. 2017;55(3):877-83.

https://doi.org/10.1128/JCM.01929-16

10. Gülmez D, Woodford N, Palepou MF, et al. Carbapenemresistant Escherichia coli and Klebsiella pneumoniae isolates from Turkey with OXA-48-like carbapenemases and outer membrane protein loss. Int J Antimicrob Agents. 2008;31(6):523-6. https://doi.org/10.1016/j.ijantimicag.2008.01.017

11. Haciseyitoglu D, Dokutan A, Abulaila A, et al. The First Enterobacter cloacae Co-Producing NDM and OXA-48 Carbapenemases and Interhospital Spread of OXA-48 and NDM-Producing Klebsiella pneumoniae in Turkey. Clin Lab. 2017;63(7):1213-22.

https://doi.org/10.7754/Clin.Lab.2017.170120

12. Kahraman EP, Toptan H, Otlu B ve ark. Karbapenemaz üreten Klebsiella pneumoniae Suşlarında bla OXA-48 benzeri genlerin araştırılması. Mikrobiyol Bul. 2019;53(2):134-43. https://doi.org/10.5578/mb.67914

13. Kutlu HH, Us E, Tekeli A. Bir Üniversite Hastanesinde 2010-2014yıllarıarasındaizoleedilen Enterobacteriacea türlerinin karbapenemaz genlerinin araştırılması ve moleküler epidemiyolojisinin belirlenmesi. Mikrobiyol Bul. 2018;52(1):1-12.

https://doi.org/10.5578/mb.66156

14. Messaoudi $A$, Haenni $M$, Bouallègue $O$, et al. Dynamics and molecular features of OXA-48-like-producing Klebsiella pneumoniae lineages in a Tunisian hospital. J Glob Antimicrob Resist. 2020;20:87-93. https://doi.org/10.1016/j.jgar.2019.07.005

15. Monteiro J, Widen RH, Pignatari ACC, Kubasek C, Silbert S. Rapid detection of carbapenemase genes by multiplex real-time PCR. J Antimicrob Chemother. 2012;67(4):906-9. https://doi.org/10.1093/jac/dkr563

16. Nordmann P and Cornaglia G. Carbapenemaseproducing Enterobacteriaceae:a call for action! Clin Microbiol Infect. 2012;18(5):411-2. https://doi.org/10.1111/j.1469-0691.2012.03795.x

17. Omnia A. Shaker, Howayda E. Gomaa, Shereen A. ElMasry, et al. Evaluation of Combined Use of Temocillin Disk and Mastdisks Inhibitor Combination Set Against Polymerase Chain Reaction for Detection of Carbapenem-Resistant Enterobacteriaceae. Open Access Maced J Med Sci. 2018;6(2):242-7. https://doi.org/10.3889/oamjms.2018.090

18. Ortega A, Sáez D, Bautista V, et al. Carbapenemaseproducing Escherichia coli is becoming more prevalent in Spain mainly because of the polyclonal dissemination of OXA-48. J Antimicrob Chemother. 2016;71(8):21318. https://doi.org/10.1093/jac/dkw148

19. Podschun R and Ullmann U. Klebsiella spp. As nosocomial pathogens:Epidemiology, taxonomy, typing methods, and pathogenicity factors. Clin Microbiol Rev. 1998;11(4):589-603. https://doi.org/10.1128/CMR.11.4.589

20. Poirel L, Naas T, Nordmann P. Diversity, epidemiology, and genetics of class $D$-lactamases. Antimicrob Agents Chemother. 2010;54(1):24-38. https://doi.org/10.1128/AAC.01512-08

21. Potron A, Nordmann P, Poirel L. Characterization of OXA-204, a carbapenem-hydrolyzing class D $\beta$-lactamase from Klebsiella pneumoniae. Antimicrob Agents Chemother. 2013;57(1):633-6. https://doi.org/10.1128/AAC.01034-12

22. Teethaisong Y, Eumkeb G, Nakouti I, et al. A combined disc method with resazurin agar plate assay for early phenotypic screening of KPC, MBL and OXA-48 carbapenemases among Enterobacteriaceae. J Appl Microbiol. 2016;121(2):408-14. https://doi.org/10.1111/jam.13196

23. Temiz H, Özbek E, Vural DG, Özekinci T. Klebsiella izolatlarının antimikrobiyal direnç oranlarının değerlendirilmesi. J Appl Microbiol. 2016;121(2):40814. 
24. Wayne PA. Performance standards for antimicrobial susceptibility testing. Clinical and Laboratory Standards Institute:CLSI Document M100-S25, (2015).

25. Zarakolu P, Eser OK, Aladag E, et al. Epidemiology of carbapenem-resistant Klebsiella pneumoniae colonization:a surveillance study at a Turkish university hospital from 2009 to 2013. Diagn Microbiol Infect Dis. 2016;85(4):466-70.

https://doi.org/10.1016/j.diagmicrobio.2016.05.012 